\title{
Effect of Capital Structure on the Relationship Between Corporate Governance and Corporate Value of Companies Listed at the Nairobi Securities Exchange
}

\author{
David Onguka ${ }^{1 *}$ Professor Cyrus M. Iraya ${ }^{2} \quad$ Dr. Winnie L. Nyamute ${ }^{2}$ \\ 1.PhD Student, School of Business, Department of Finance and Accounting, University of Nairobi, \\ P.O Box 58823, 00200, Nairobi, Kenya \\ 2.Lecturers, School of Business, Department of Finance and Accounting, University of Nairobi, \\ P.O Box 30197, 00100, Nairobi, Kenya
}

\begin{abstract}
The capital market authorities of different areas have from time to time issued regulations and guidelines for good corporate governance practices ensuring thorough and proper management of listed companies to align the interest of all stakeholders, ensure firm sustainability, and optimize corporate value. Despite these interventions, cases of corporate underperformance and failures attributed to financial distress and governance weakness continue to increase in magnitude and frequency. The main objective of the study was to determine the intervening effect of capital structure on the relationship between corporate governance and corporate value of companies listed at the Nairobi Security Exchange (NSE). The study tests hypothesis that there is no intervening effect on the capital structure on the relationship between corporate governance and corporate value for companies listed at the NSE. The key theories underpinning the study were agency theory as the main guiding theory and the trade-off theory. The data was acquired from past audited financial statements of companies listed at the NSE. The study used a census survey for sixty-four listed companies at the NSE. The analysis covered a period of five years between 2013 and 2017. Corporate Governance was measured by a composite of Board Independence, Board Size, Board Composition, and Corporate Gender Diversity. Capital structured was measured by leverage Different performance metrics have been used to evaluate corporate value worldwide by regulators and scholars. This study used Tobin - Q which has become an important tool for measuring corporate performance due to its incorporation of the market value of shares in its computation. The study adopts a positivism research philosophy and descriptive design. Descriptive statistics and diagnostic tests were conducted on the data thereafter inferential statistics namely correlations analysis and regression analysis were used to test the hypothesis. The panel data procedure was considered more appropriate as the sample data contained both cross-sectional and time-series data. The diagnostics tests were used to test for bias in the model and the regression used to test the strength and direction of the variables. Baron and Kenny (1986) approach was used to test the intervening effect of capital structure on the relationship between corporate governance and corporate value. The finding was that capital structure had no significant intervening effects on the relationship between corporate governance and corporate value. This research contributes to the line of literature that examines the desirability of corporate governance in enhancing corporate value. These insights in explaining corporate governance, capital structure, and corporate value relationships are useful for academic understanding and business and public policy formulations.
\end{abstract}

Keywords: Corporate governance, capital structure, agency theory, trade off theory, corporate value.

DOI: $10.7176 /$ RJFA/11-17-10

Publication date:October $31^{\text {st }} 2020$

\section{Introduction}

If buyers and primary producers could locate each other efficiently, purchase or process any or all needed items and services at no transaction cost and make their decisions with freely available information then corporations would have little or no scope for mediating these direct transactions. Corporate governance involving directing, managing systems, resources, and people are therefore key in value creation. Studies have shown that the application of prudent corporate governance rules creates confidence in investors to obtain profits (Alqisie, 2014). Agency theory is the anchoring theory of the study because it is instrumental in the conceptualization of the relationship between corporate governance and firm value. It may result in agency conflict as management starts to pursue selfish interest's contrary to those of shareholders (Calomiris \& Carlson, 2016). It helps us understand the importance of having a strong corporate governance mechanism in firms and how they impact their performance. The theory informs us of the importance of managing the relationship between owners and managers which influences the performance of corporations to a great extent. The intervening relationship between corporate governance and firm valued was conceptualized by the trade-off theory. The theory asserts that companies would prefer to finance through debt until the benefits resulting from tax shields equal the costs of financial distress and bankruptcy. The theory was authored by Jensen and Meckling (1976) who postulated trade-off scenario between a company's optimal debt-equity ratio and impact of bankruptcy costs, taxes, and agency costs. 
The aim of this study is to establish the cause of the company's underperformance and failures which continue to increase in magnitude and frequency at NSE despite the various measures that have been established by regulatory authorities such as the Central Bank and CMA. Although the improvement and implementation of corporate governance principles and regulations have contributed to improving corporate performance significantly, there are still increasing cases leading to failures and underperformance (Dominic \& Memba, 2015). We have recently experienced Uchumi and Nakummat Supermarkets being put under management by CMA in 2015, as well as the continuing huge losses by Kenya Airways and constant bailout by the Government of Kenya Airways, Mumias Sugar among others. Several studies have attributed this problem to ineffective corporate governance and financial difficulties (Peters \& Bagshaw, 2014). Recent studies postulated that this reflects deepseated corporate governance shortcomings such as complacency of board oversight, poor corporate governance, and lack of strategic foresight by the management (Vincent et al., 2015 and Opiyo, 2013).

\subsection{Corporate Governance}

Corporate governance can be said to be a power relationship between shareholders, directors, and top management in determining the direction and the performance of the company. It is therefore an internal process of directing and governing a company's activities and business through people, systems, and procedures to achieve the objectives of shareholders and other stakeholders (Solomon et al., 2013). Corporate governance can be defined as rules and policies set out by management to regulate affairs and have efficient management of the company's resources to enhance the value of the company and attain maximum shareholders returns (Haque \& Arun,2016). It is therefore a framework of rules, relationships, systems, and processes that provide a structure for exercising authority, securing financial and other resources, and controlling corporations to enable companies create to value while providing accountability and control systems to hold actors responsible for their individual and collective actions.

It is widely believed that good corporate governance is an important factor in improving the value of a firm in both developing and developed financial markets. However, the relationship between corporate governance and the value of a firm differs in developing and developed financial markets due to disparate corporate governance structures in these markets resulting from the dissimilar social, economic, and regulatory conditions in these countries. There is a need to understand the differences which affect the value of a firm for academic investigations, financial and management practices, and public regulation of markets and corporations (Bader, 2016).

In their attempt to find appropriate measurement of corporate governance researchers have focused on measuring the attributes of the board of directors and their function. But it is not the mere existence of the structures or attributes that count. Corporate governance should be linked more to duty rather than mere structures. This means that meeting the attribute-requirements alone is not a panacea to good governance. The most important thing is the commitment to duty. Research has not established a common set of elements to be used as measuring variables for corporate governance. Different researchers use different boards of directors' attributes as a proxy to measure corporate governance and this creates inconsistency (Carty \& Weiss, 2012 and Proudfoot et al., 2016). Such attributes include board size, female representation on boards (gender), CEO duality, board independence, board composition, and more.

\subsection{Capital Structure}

Stiglbeuer (2011) defines capital structure as a blend of debt and equity which the company uses to fund its activities and notes that companies generally employ different mix ratios in their financing activities. High financial leverage may result in improved efficiency by reducing agency costs as a result of fear of bankruptcy which would result in losses to managers in form of salaries, reputation, perquisites, and pressure to generate cash to meet periodic loans and interest repayments. It can be argued, therefore, that an optimal capital structure can be attained if there exists a tax sheltering benefits provided an increase in debt level equal to the bankruptcy cost.

Githira and Nasieku (2015) pointed out that corporate governance influences shareholder value through decisions on capital structure adoption and changes. Management decisions on the capital structure may have a fundamental impact on corporate performance as was evidenced by some Indonesian airlines companies that highly leverage capital structure led to firm failure (Alqisie, 2014). The importance of capital structure must be evaluated in terms of its impact on the value of the firm. In the context of this study, we establish whether increasing leverage imposes discipline on management or propels management to exert more effort thereby enhancing corporate value. According to Dumont and Svensson 2014, it is possible that debt can magnify financial distress in a firm. Financial distress is costly because it adversely affects shareholders and managerial investment decisions, thus inducing substantial inefficiency in the firm. If debt capital affects firm performance, then the prescription to the managers would be to mix debt and equity capital and that an optimum capital structure is located for each firm. Firm performance could be influenced by the amount of debt in capital structure, and this traced to corporate governance.

Leverage has been widely used as a capital structure measurement. It weighs the capability of a company to 
deal with trade downturns, meaning that a company with high leverage is more susceptible to trade shocks because it has little ability to service debt (Waroka, Herrera \& Abdullah, 2011). In some studies, reviewed the researchers used the ordinary least square regression (OLS) model to build a relationship between performance and capital structure (Bader, 2016 and Beck \& Wiersema, 2013). Okiro et al. (2015) applied leverage and liquidity to measure the capital structure. Others have applied Long term debt, short term debt, debt to equity ratio among others (Velte, 2017 and Wanyoike \& Nasieku, 2015).

\subsection{Corporate value}

Corporate Value realized is an assessment of the fulfilment of a firm's economic goals and this has long been an issue of interest in managerial research. Value is best looked at in two ways that are, end results, and means to achieve the results. According to Anderson, Becker \& Campbell (2014), Corporate value or performance enables one to distinguish the outcome of organizational activities. It can either be financial or non-financial. The nonfinancial value is measured using operational Key Performance Indicators such as Market share, innovation rate, or customer satisfaction (Haque \& Arun, 2016).

A good value indicator should be measurable, applicable, and important to the company (Carter \& Greer, 2013). The concept of value is a controversial issue in finance largely due to its multidimensional meanings. Research on firm value emanates from organization theory and strategic management (Stiglbeuer, 2011). Corporate value can take many forms depending on who and what the measure is for. Different stakeholders require different value indicators to enable them to make informed decisions. The content, format, and frequency of the report depend on who needs the information and for what purpose.

Shareholders would want to be certain about the viability, growth, profitability, return on investment, and continued financial sustainability of the firm (Lishenga, 2012). Traditional performance measures include return on equity (the ratio of income after taxes divided by total common equity capital); return on assets (the ratio of net income to average total asset); cost-to-income ratio (ratio of operating expenses to operating income generated) and net interest margin (net interest income divided by total earning assets). Tobin's Q calculation which measures share value growth. Return on asset (ROA) measures the effectiveness of capital employed as well as giving a basis for those who want to invest to measure the income generated from venturing in capital resources (Okiro, 2014).

\subsection{The Nairobi Securities Exchange}

Capital markets are considered efficient and critical tools for the development of the economy (CMA, 2019). Ali (2018) argues that the capital market is an important institution in the development of the economy by channelizing resources, promoting reforms to strengthen the financial sector and use of savings amongst competitive uses which are critical for the efficiency of economy. They help individuals to invest in their future needs and channelize these savings to support the economy. The Nairobi Security Exchange (NSE) was set up by the London Stock Exchange in 1920 and was registered locally in 1954 under the Society Act (Vincent et al., 2015). Its mandate is to promote, develop, support, and discharge all the functions of the security market. It plays the role of capital mobilization, creating investment opportunities as well as serving as the barometer for the health of the country's economy. The NSE is the regulatory body charged with ensuring compliance to corporate governance principles intended to eliminate weaknesses identified by previous studies which were expected to ensure effective corporate governance for optimal corporate value.

Nevertheless, some companies registered at the NSE keep exhibiting fundamental weakness and poor performance (Dominic \& Memba, 2015). The argument on whether it is the control failure, financial distress or governance weakness or combination of these that are responsible for the failure continues. The issues that have stimulated interests in the phenomenon of corporate governance points to cause of governance crises. These include weak legal and regulatory systems, inconsistent accounting and auditing standards, and poor banking practices. Thin and poorly regulated capital markets, ineffective oversight by corporate boards of directors, and little regard for the rights of minority shareholders are also problems with respect to Corporate Governance (CBK, 2019).

\subsection{Research Problem}

Poor corporate governance has proven in part to be a major impediment to improving the corporate value of firms besides not being able to attract capital in an environment with ever-increasing capital mobility. Corporate governance and the choice of the capital structure may help mitigate these agency costs. It is an important factor in improving the value and performance of the firm and the impact differs from country to country because of different structures resulting from dissimilar social, economic, and regulatory conditions.

Increasing cases of corporate underperformance, bankruptcies and liquidation has been attributed to financial distress and corporate governance weaknesses in equal measure. The attempt made by capital market authority and Central Bank of Kenya to strengthen corporate governance and financial discipline through the implementation 
of improved governance principles and financial discipline through regular reporting and oversight has only has had some positive impact but not enough to arrest the increasing cases and frequency of such failures. Corporate governance has been debated in the context of state ownership and private ownership of corporations where corruption, mismanagement, and government subsidization of failing listed enterprises like Kenya Airways, Mumias Sugar among others have been the defining features. Cement maker ARM and fashions retailer Deacons (EA) were put under administration in 2017 due to too high debt and excess losses. The performance trend of listed firms at the NSE has not been impressive in the last decade. NSE index performance trend has been on a downwards trend for the last 10 years and touched its lowest in March 2019 (CBK, 2019). The problem seems to arise from lack of clarity on the reason for increasing underperformance and failures even with improvements through new acts, better laws, and stronger regulations, being put in place to reduce or stop it.

There are conflicts in Agency and trade-off theories. Anderson et al. (2014) concluded that researchers have failed to find any convincing connection between capital structure and the best practices in Corporate Governance and Corporate Value. Due to the inconclusiveness and extreme findings from the studies that have already been done, there is a need to do more research to ascertain the influence capital structure has on the relationship between corporate governance and corporate value of listed firms. It is these pretexts that this study sought to analyse the intervening effect of capital structure on the relationship between corporate governance and corporate value. Most research on corporate governance's effect on performance has employed either a cross-sectional or time series approach (Haque \& Arun, 2016; Rose, 2017 and Lumumba, 2015). This study adopted a descriptive longitudinal design using panel data regression analysis. The panel data procedure was considered more appropriate as the sample data contained both cross-sectional and time-series data. using pure time-series data requires a long run of data simply to get enough observations to be able to conduct any meaningful hypothesis test.

A number of studies have been done in developed countries but the outcome of these studies - although conflicting in many cases - cannot be adopted wholeheartedly in the developing countries because of the social, cultural, and economic dissimilarities between developing and developed countries (Carter \& Greer, 2013; Chen, 2012 and Hasan \& Butt, 2009). Other studies have considered individual variables relationships on firm performance. The question is what is the intervening effect of capital structure on the relationship between corporate governance and corporate value?

\subsection{Research Objective}

To assess the effect of capital structure on the relationship between corporate governance and corporate value of NSE listed firms.

\section{Literature Review}

\subsection{Agency Theory}

This theory was advanced by Jensen and Meckling (1976) who argue that separation of ownership from control creates an agency problem whereby the management operating the company to satisfy their interest and not necessarily that of the owners. Stiglbauer (2011) refers to the theory as a neoclassical economic theory and posits that it is usually the starting point for any debate on corporate governance. According to Morrison and Jenson (2013) when there is information asymmetry, the agents are likely to pursue an interest that may hurt the principal.

Agency costs include the costs of structuring, monitoring, and bonding a set of contracts among agents with conflicting interests, plus the residual loss incurred because the cost of full enforcement of contracts exceeds the benefits (Wagana \& Karanja, 2015). The theory stems from the agency relationship that exists in a corporate environment in which there is a fiduciary duty on the management (agent) to the shareholders (Principal) to work for the principal's best interest.

Critics of the theory point out that it focuses on divergent relationships alone thereby overlooking the convergence of relationships between various actors and their inter-dependencies (Hasan \& Butt, 2009). Donaldson and Davies (1994) findings also indicate that where a manager has served in a company for a long time, help shape and mould its form and directions, there is likely to be a melding of individual self-esteemed with corporate prestige. Other stakeholders like employees and banks are also likely affected by the appropriation policy of management and may oppose or expose such actions.

The theory helps us understand the importance of having strong corporate governance mechanisms in firms and how they impact their performance. Kenya's financial institutions are managed by executives on behalf of shareholders. The agency problems are evident in most scandals that have faced some of the financial institutions under this study. This theory is therefore relevant in this study, as it informs us of the importance of managing this relationship between owners and managers which influences the performance of corporations to a great extent.

\subsection{The Trade-Off Theory}

The intervening effect of capital structure on the relationship between corporate governance and corporate value is supported by the trade-off theory. The theory was authored by Jensen and Meckling (1976) who postulated 
trade-off scenario between a company's optimal debt-equity ratio and impact of bankruptcy costs, taxes, and agency costs. The risk of collapse of the company forces managers to work harder to generate enough cash flow to keep the business afloat. Theoretically, capital structure is positively correlated with company value and therefore leverage utilized to minimize agency expenses and enhance company value (Zabri, Ahmad \& Wah, 2016). This provides a testable link on whether capital structure affects company value and is affected by corporate governance.

Trade-off theory argument on the existence of an optimal capital structure that optimizes corporate value will motivate management to implement corporate governance best practices that would enable them to achieve this debt level. The uniqueness of this optimal tax level to the different companies means that investors would prefer investing in corporation with higher optimal level gain accelerated returns both from debt and capital invested. The tax benefit of debt and control of free cash flow problems pushes firms to use more debt financing which also positively influences management to invest in projects with positive cash flow thereby optimizing corporate value. One of the main empirical prediction of this theory is that debt ratios will tend to be mean-reverting as firms use the external capital markets strategically to keep their values at a close to their optimum (Driffield, Mahambare \& Pal, 2005).

Critics of this theory point out that high debts level result in financial distress and bankruptcy and may therefore result in reduction of corporate value. In perfect and efficient markets, Modigliani and Miller (1958) showed that capital structure is irrelevant to the cost of capital, and thus firm value which contradicts the theory. The relevance of this theory is the ability to support the conceptualization of the intervening effect of capital structure on the relationship between corporate governance and corporate value. The trade-off theory of capital structure predicts that firms will choose their mix of debt and equity financing to balance the costs and benefits of debt.

\subsection{Corporate Governance, Capital Structure, and Company Value}

Studies relating corporate governance and corporate performance have yielded contradictory and inconclusive results. Some studies have documented positive relationships while others have reported either negative or no relationships. The possible explanation for the conflicts and contradictions could be that intervention and moderation effects are excluded from the studies, the differences in the attributes of predictor and dependent used, as well as methodological differences.

Adera et al. (2015) examined the link between debt-equity ratio and stock values of NSE manufacturing companies. They applied the explanatory non-experimental research design. A census survey method was employed where all the nine companies were studied. Pearson, Correlation - (2-tailed) Pearson analysis was employed. Research findings indicated that a significant positive correlation underlies long-term debts, ordinary share capital, preference share capital and reserves, and corporate performance of manufacturing firms. The research did not consider moderating variables on the relationship nor the corporate governance influence in the relationship. Recent empirical research shows that implementing corporate governance best practices remains a challenge for listed companies in Kenya and regionally. Such best practices include protecting shareholders' rights and defining clearly what the role of stakeholders is and what the responsibilities of the board of directors are towards optimizing firm value. Providing an answer to this gap is foundational and fundamental in ensuring optimal corporate growth and performance hence the need for the current study.

Dumont and Svensson (2014) studied the debt-equity structure and firm performance of the Swedish public companies. They applied a large scale quantitative cross-sectional. Relationships were tested with multiple regression models and development of financial statement data that have been tracked over an 8-year period. The research found a negative relationship underlying debt-to-equity and return on equity for Swedish firms. This means that companies can increase their return on equity by decreasing their debt-to-equity levels. The study has not considered ownership structure influence on the relationship. These study findings may also not be applicable in the local context as it was done in a developed market therefore there is a need to investigate the relationship of corporate governance with firm value in the local and regional markets.

Sen, Das, and Sharma (2014) examined the connection underlying debt-equity ratio and stock value performance in the Amman stock market firms. It utilized hierarchical multiple regression model HMR to determine the impact of capital structure on firm performance; they used 76 firms (53 industrial firms and 23 service corporation) for the time frame (2009-2013). It was concluded that capital structure affiliated itself significantly and statistically on firm performance per the sample. No notable distinction could be seen of the effect of the financial leverage between high financial leverage firms and low financial leverage firms on their performance. It concluded that no major difference underlies the financial leverage of high growth firms and low growth firms on the performance. The study did not include an intervening variable of and moderating variable in the relationship. They found a negative link between capital structure and company value. In terms of geographical context, this study does address the key challenges facing corporate governance reforms in the developing countries and particularly east African countries such as corruption, weak regulatory enforcement, inactive 
shareholders, and predictable leadership based on tribal arithmetic rather than real performance which are more foundational and fundamental in tackling corporate underperformance.

Most of the studies on the three concepts have been conducted in developed economies that differ in terms of market efficiencies, legal as well as regulatory environments. Further limited studies have evaluated the intervention effects of capital structure at the same time. Given the contextual and methodological differences, the inconclusive and sometimes conflicting results, this is an area that requires the current and further research.

\subsection{The Conceptual framework}

Figure 1 presents a conceptual framework model of the intervening effect of corporate governance and corporate value. Corporate governance can affect corporate value indirectly through capital structure. Directors, who are appointed by shareholders at the AGM, do not engage in the daily operational activities of the firm rather they monitor the managerial activities and approve critical managerial decisions in the firm. One of the key decision management makes which requires the director's approval is the capital structure decision. The hypothesis therefore proposes the intervening effect of capital structure on the relationship between corporate governance and corporate value. Both Trade-off theory and agency theory supports this hypothesis.

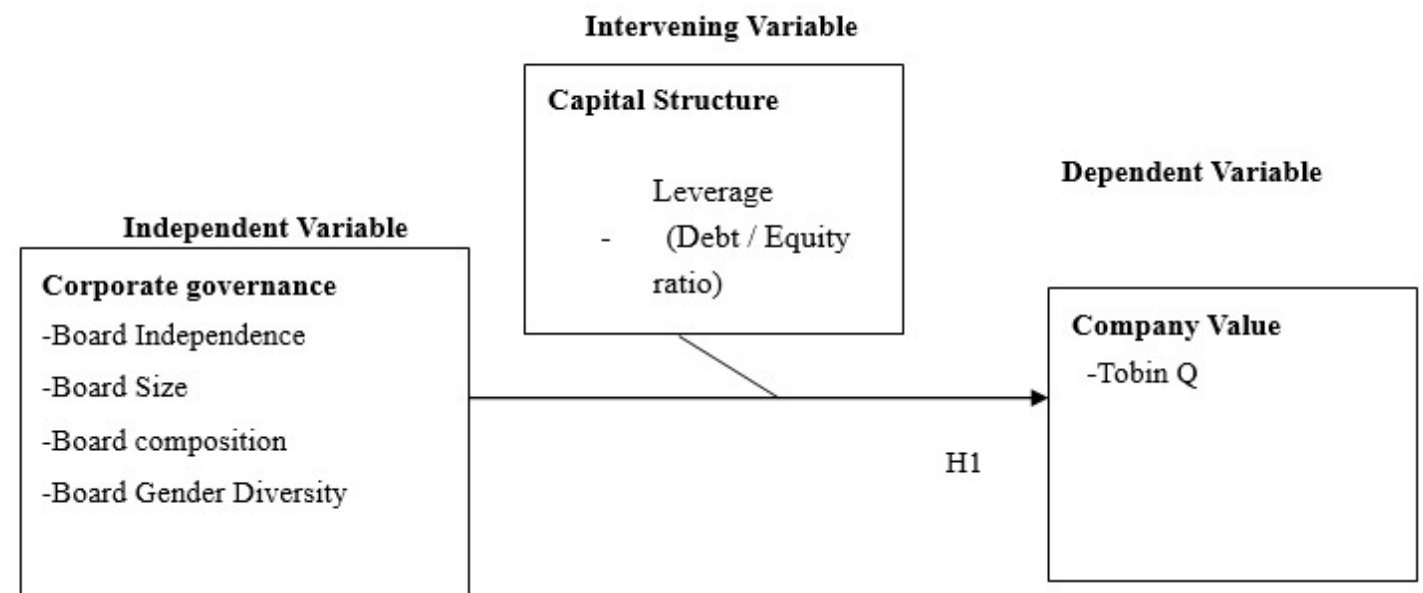

Figure 1: The Conceptual Model

Source: Author (2020)

\section{Research Methodology \\ 3.1 Research Philosophy}

Solomon et al. (2013) defined research philosophy as a conviction or belief about the way and method in which data about a phenomenon should be gathered, analyzed, and used. It is the process of scientific practice based on a researcher's assumptions about the world and the nature of knowledge (Creswell, 2013). Bhaskar (2014) state that positivist studies generally attempt to test a theory, to increase the predictive understanding of phenomena. Alqisie (2014) supports this proposition by stating that positivism is applicable if there is evidence of formal propositions, quantifiable measures of variables, hypothesis testing, and the drawing of inferences about a phenomenon from the sample to a stated population. This study was therefore premised on the positivism research philosophy as it tested several quantitative hypotheses.

\subsection{Research Design}

Research design is a scheme used to guide a research study to enable the study to address the research problem. It is the structure of research; it is the glue that holds all elements of the research project together. It can therefore be defined as the plan and structure of investigation of a phenomenon that has been conceived to enable the research to get answers to research questions (Kothari, 2004). Robbins and Judge (2017) defined a research design as a procedural blueprint embraced by a researcher to respond to questions objectively, validly, economically, and accurately. The descriptive design was appropriate for this study since the key variables in the study were defined and the study clearly stated hypothesis and investigative questions. Cooper and Schidler (2008) supported this position by stating that the descriptive design is appropriate for a study that has already a stated hypotheses or investigative questions. The study adopted a descriptive longitudinal design using panel data. The panel data procedure was considered more appropriate as the sample data contained both cross-sectional and time-series data (Mang'unyi, 2011). 


\subsection{Population and study sample}

Cooper and Schindler (2008) define the population as an entire group of individuals, events or objects having common characteristics that conform to a given specification. The population of the study comprised of all the 64 companies listed at the NSE as of 31st December 2017. The quoted companies are preferred as they have a defined structure, a legal mandate to operate, are likely to exhibit elaborate linkages between research variables and provide a basis for determining the market value and performance in an objective manner. The research adopted a census method due to the small number of qualifying companies at the NSE. Creswell (2013) opinioned that in the case of a small population in the study, less than 100, then the broader population can be integrated as part of the research with a census taken. In the present research, a census survey was applied as the target population was small thus no sampling was undertaken. This use of census fulfilled the requirement of efficiency, representativeness, and reliability (Dominic \& Member, 2015).

\subsection{Data Collection}

Gujarati (2003) defined data collection as the precise, systematic gathering of information relevant to the research problems using methods such as interviews, participant observations, focused group discussion, narratives, and case histories. This research employed quantitative secondary data collected in Microsoft excel for a five-year period. The data acquired from past financial statements of companies listed at the NSE. The investigation concerning the determinants of Corporate Governance, Capital Structure, and Corporate Value was done using data gathered from 58 firms from 2013 to 2017. Secondary Data was obtained from companies' websites, financial statements, and other records filed with NSE. Where necessary data were not obtained, the same was requested directly from the company's management.

\subsection{Diagnostic Tests}

Several diagnostic tests have been used to justify the validity of regression results to determine whether the regression model is unbiased. These were done given that it is impractical to achieve accurate and reliable deductions about reality when the population from which the sample is derived is invalid (Creswell 2013). The classical linear regression model is based on several assumptions including linear relationship, multivariate normality, no or little multicollinearity, no autocorrelation, and homoscedasticity. Linear regression analysis requires that there is little or no autocorrelation in the data. Autocorrelation occurs when the residuals are not independent of each other. The Durbin - Watson (1951) statistic $(1.5<\mathrm{d}<2.5)$ was used to test the autocorrelations in the panel data. The ANOVA test of linearity was used to check for linearity of the relationships between the independent and the data of the dependent variables. Nonlinearity was considered significant if the computed $\mathrm{F}$ value for the nonlinear component was below 0.05 .

Multicollinearity occurs when the independent variables are not independent of each other meaning one independent variable can be linearly predicted from the others with some reasonable degree of accuracy (Kothari, 2004). The presence of multicollinearity was assessed using the VIF (Tolerance) test. Multicollinearities exist if the value of VIF is higher than 10 and the tolerance value is not far from 1 . The classical linear regression model assumes that the data is homoscedastic (literally, same variance). The heteroskedasticity problem arises in the data when the variance of the residuals is not constant across all observations. The Levene's test was used to assess the assumption that variances of the populations from which different samples were drawn were equal. The Levene's statistic tested the null hypothesis that the population variances are equal (called homogeneity of variance or homoscedasticity). The linear regression analysis requires all variables to be multivariate normal. Normality was checked with a goodness of fit test, the Kolmogorov-Smirnov test. In addition, the Shapiro-Wilk (1965) test, which is a more robust test of normality, was also adopted.

\subsection{Data Analysis}

Carty and Weiss (2012) define data analysis as the application of reasoning to understand the data that has been gathered with the aim of determining consistent patterns and summarizing the relevant details revealed in the investigation. Multiple regression analysis was used to test the strength and direction of variables. Statistical program for social sciences (SPSS) version 26 was used to analyze descriptive and inferential statistics used to measure the variables. The above analysis was consistent with those used in the previous studies to test the main effect, intervention, moderation, and joint effect (Okiro,2014 and Mang'unyi, 2011).

To determine the intervening impact of Capital Structure on the Relationship between Corporate Governance and Corporate Value, the four steps approach demonstrated by Baron and Kenny (1986) was applied to test hypothesis.

Step 1: $\mathrm{CV}_{\mathrm{it}}=\beta_{0}+\beta_{1} \mathrm{CG}_{\mathrm{it}}+\varepsilon_{\mathrm{it}}$

Where $\mathbf{C V}$ represents Corporate Value (measured by Tobin Q), $\boldsymbol{\beta}_{\mathbf{0}}$ is the intercept or Constant, $\boldsymbol{\beta}_{\mathbf{1}}$ is regression coefficient, $\boldsymbol{\varepsilon}$ is a random error term that accounts for the unexplained variations, $\mathbf{i}$ is a number of companies used in the sample and $\mathbf{t}$ are the duration of the research, $\mathbf{C G}$ is the composite of Corporate Governance (Measured by 
the weighted average of Board Independence, Board Size, Board Composition, and Board Gender Diversity. A significant $\boldsymbol{\beta}_{1}$ confirms a relation between Corporate Governance and the Company's Value.

Step 2: $\mathrm{CS}_{\mathrm{it}}=\beta_{0}+\beta_{1} \mathrm{CG}_{\mathrm{it}}+\varepsilon_{\mathrm{i}}$

Where.

CS- Capital Structure score of parameters (Company Leverage)

$\boldsymbol{\beta}_{\mathbf{0}}-$ and $\mathrm{CG}$ are as defined above

This equation confirms that the independent variable is a predictor of the mediators. If the mediator is not relating to the causation variable, then it cannot mediate the relationship. In this case, $\beta_{1}$ must be significant for a relationship to exist.

Step 3: The third step involves a simple regression analysis with CS (Capital Structure) predicting CV (Corporate value).

$\mathrm{CV}_{\mathrm{it}}=\beta_{0}+\beta_{1} \mathrm{CS}_{\mathrm{it}}+\varepsilon_{\mathrm{i}}$

Step 4: This entailed a multiple regression analysis with CG (Corporate Governance) and mediator (Capital Structure) predicting CV (Corporate Value).

$\mathrm{CV}_{\mathrm{it}}=\beta_{0}+\beta_{1} \mathrm{CG}_{\mathrm{it}}+\beta_{2} \mathrm{CS}_{\mathrm{it}}+\varepsilon_{\mathrm{i}}$

Where $C V, C G, C S$, and $\beta_{0}$ are defined in steps one and two. $\beta_{1}$ and $\beta_{2}$ are the regression coefficients. This model confirms that the mediator is a significant predictor of the response variable while controlling for the causation variable. $\beta_{2}$ must be significant and $\beta_{1}$ should be smaller in absolute value as compared to step value there to be an intervening impact.

Intervention occurs when Corporate Governance predicts Corporate Value, Corporate Governance predicts Capital Structure, Capital Structure predicts Corporate Value and still, Corporate Governance predicts Corporate Value when Capital Structure is in the model

\subsection{Descriptive statistics}

Descriptive statistics results were used in describing the basic features of data by providing simple summaries about the sample and the measures used. Sekaran and Bougie (2009) contend that; along with simple graphics analysis, descriptive analysis virtually forms the basis of every quantitative analysis of data. The descriptive statistics refer to the measurement of data in terms of the minimum, maximum, mean, standard error of estimates. It also includes measures of symmetry - skewness and flatness or sharpness of data - kurtosis.

The results of the descriptive statistics of all the study variables for the number of observations (N) are shown in table 1 to 2 below:

Table 1: Corporate Governance Descriptive Statistics

\begin{tabular}{|l|l|l|l|l|l|l|l|l|l|}
\hline & $\mathrm{N}$ & Minimum & Maximum & Mean & Std. Deviation & \multicolumn{2}{|c|}{ Skewness } & \multicolumn{2}{|c|}{ Kurtosis } \\
\cline { 2 - 10 } & Statistic & Statistic & Statistic & Statistic & Statistic & Statistic & $\begin{array}{l}\text { Std. } \\
\text { Error }\end{array}$ & Statistic & $\begin{array}{l}\text { Std. } \\
\text { Error }\end{array}$ \\
\hline $\begin{array}{l}\text { Board } \\
\text { Independence }\end{array}$ & 290 & .05154 & .65967 & .4155420 & .13845227 & -.613 & .143 & -.131 & .285 \\
\hline Board Size & 290 & .04850 & .85524 & .5528597 & .17567500 & -1.147 & .143 & .787 & .285 \\
\hline $\begin{array}{l}\text { Board } \\
\text { Composition }\end{array}$ & 290 & .34210 & .68948 & .5551251 & .07274991 & -.326 & .143 & -.678 & .285 \\
\hline $\begin{array}{l}\text { Board Gender } \\
\text { Diversity }\end{array}$ & 290 & .01058 & .62033 & .2538652 & .08718682 & -.300 & .143 & 1.441 & .285 \\
\hline $\begin{array}{l}\text { Corporate } \\
\text { Governance }\end{array}$ & 290 & .27486 & .56677 & .4443474 & .05739825 & -.510 & .143 & .299 & .285 \\
\hline
\end{tabular}

Table 1 above shows that Board Independence, Board Size, Board Composition, Board Gender Diversity,

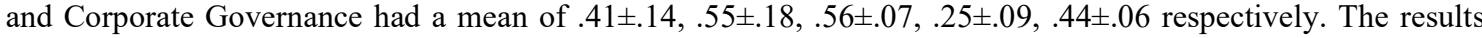
show that Board Independence and Board Composition have negative Kurtosis while Board Size, Board Gender diversity, and Corporate Governance have positive Kurtosis. All the variables have negative Skewness.

Table 2: Corporate Value Descriptive Statistics

\begin{tabular}{|l|l|l|l|l|l|l|l|l|l|}
\hline & $\mathrm{N}$ & Minimum & Maximum & Mean & \multicolumn{2}{|l|}{$\begin{array}{l}\text { Std. } \\
\text { Deviation }\end{array}$} & \multicolumn{2}{|c|}{ Skewness } & \multicolumn{2}{c|}{ Kurtosis } \\
\cline { 2 - 10 } & Statistic & Statistic & Statistic & Statistic & Statistic & Statistic & $\begin{array}{l}\text { Std. } \\
\text { Error }\end{array}$ & Statistic & $\begin{array}{l}\text { Std. } \\
\text { Error }\end{array}$ \\
\hline $\begin{array}{l}\text { Corporate } \\
\text { Governance }\end{array}$ & 290 & .27486 & .56677 & .4443474 & .05739825 & -.510 & .143 & .299 & .285 \\
\hline $\begin{array}{l}\text { Ownership } \\
\text { Structure }\end{array}$ & 290 & .11256 & .51648 & .3083550 & .07811537 & .060 & .143 & -.474 & .285 \\
\hline $\begin{array}{l}\text { Capital } \\
\text { Structure }\end{array}$ & 290 & .02490 & .86843 & .4035326 & .18608898 & .278 & .143 & -.562 & .285 \\
\hline $\begin{array}{l}\text { Corporate } \\
\text { Value }\end{array}$ & 290 & .10780 & 2.36245 & 1.0063867 & .38895525 & .336 & .143 & -.050 & .285 \\
\hline
\end{tabular}


Table 2 above shows that composite Corporate Governance, Capital Structure and Corporate Value had a mean of $.44 \pm .06, .31 \pm .08, .40 \pm .19, .1 .01 \pm .39$ respectively. The results show that Ownership Structure, Capital Structure and Corporate Value have positive Skewness while Corporate Governance has a positive Skewness. It also shows that Capital Structure, and Corporate Value have negative Kurtosis while Corporate Governance has a negative Kurtosis.

\subsection{Results of Diagnostic Tests}

The statistical assumptions including regression and statistics applied were tested. These tests were done on independence, homogeneity, normality, linearity and Multiple co linearity.

\begin{tabular}{|l|l|c|c|c|c|c|}
\hline & Assumption (Test) & $\begin{array}{c}\text { Normality } \\
\text { (Shapiro- } \\
\text { Wilk) }\end{array}$ & $\begin{array}{c}\text { Linearity } \\
\text { (ANOVA) }\end{array}$ & $\begin{array}{c}\text { Independence } \\
\text { (Durbin Watson) }\end{array}$ & $\begin{array}{c}\text { Homogeneity } \\
\text { (Levene) }\end{array}$ & $\begin{array}{c}\text { Collinearity } \\
\text { (Tolerance) }\end{array}$ \\
\hline Variable & Attribute & $\mathrm{P}>0.05$ & $\mathrm{P}>0.05$ & $1.5<\mathrm{d}<2.5$ & $\mathrm{P}>0.05$ & VIF $10 \mathrm{Max}$ \\
\hline \multirow{4}{*}{$\begin{array}{l}\text { Corporate } \\
\text { Governance }\end{array}$} & Board Independence & 0.4 & 0.27 & 1.765 & 0.845 & 1.165 \\
\cline { 2 - 7 } & Board Size & 0.324 & 0.76 & 1.765 & 0.619 & 1.032 \\
\cline { 2 - 7 } & Board Composition & 0.24 & 0.406 & 1.765 & 0.365 & 1.231 \\
\cline { 2 - 7 } & Board gender diversity & 0.26 & 0.34 & 1.765 & 0.418 & 1.049 \\
\hline \multirow{3}{*}{ Corporate Value } & Corporate Governance & 0.401 & 0.199 & 1.978 & 0.682 & 0.993 \\
\cline { 2 - 7 } & Capital Structure & 0.302 & 0.52 & 1.978 & 0.712 & 0.866 \\
\cline { 2 - 7 } & Ownership Structure & 0.234 & 0.34 & 1.978 & 0.321 & 0.865 \\
\hline
\end{tabular}

Normality was tested using the Shapiro-Wilk test which has the power to detect departure from normality due to either skewness or kurtosis or both. The readings of the study $(\mathrm{p}>.05)$ were greater than 0.05 confirming normality. Normality assumes that the sampling distribution of the mean is normal. Linearity was tested using the ANOVA test of linearity which computes both the linear and nonlinear components of a pair of variables whereby linearity is significant if the $\mathrm{F}$ significance value for the linear component is more than 0.05 . Computed readings for the ANOVA test were all above 0.05 confirming linear relationships (constant slope) between the predictor variables and the dependent variable. The study further assessed Independence of error terms, which implies that observations are independent through the Durbin-Watson test whose statistic ranges from 1.5 to 2.5 . The test results ranged between 1.765 and 1.978 supporting the independence of error terms. Homoscedasticity was tested using Levene's test of homogeneity of variances. The test was not significant at $\alpha=0.05$ confirming homogeneity. Multicollinearity was tested by computing the Variance Inflation Factors (VIF) and its reciprocal, the tolerance. Multicollinearity is a situation in which the predictor variables in multiple regression analyses are themselves highly correlated making it difficult to determine the actual contribution of respective predictors to the variance in the dependent variable. The multicollinearity assumption has a VIF threshold value of 10 maximum (Sekaran \& Bougie, 2009). The computed tolerance for all the variables was less than 1 and therefore it's reciprocal, the VIF was between one and two, which falls within the threshold.

\subsection{Correlation Analysis}

The examination of the correlation coefficients helps in accepting or rejecting the null hypothesis that there is no correlation between the explanatory variables. The degree of the linear relationship between two variables in correlation ranges between +1 and -1 . A correlation of +1 implies that there is a perfect positive linear relationship between variables hence the concern of multicollinearity problem (Sekaran \& Bougie, 2009).

Corporate Governance, Capital Structure, and Corporate Value relationship was instituted through correlation analysis using the Pearson Product Moment Correlation Coefficient technique. Overall, the correlation coefficients were far much less than the 0.8 thresholds indicating that there was no concern for multicollinearity (Mang'unyi, 2011). Therefore, we fail to reject the null hypothesis that there is no correlation between the explanatory variables. In this study, the results of the correlations are reported at a significant level of 0.05 and 0.01 consistent with other studies such as Alqisie (2014).

The results are shown below

Table 4: Correlation Matrix for Individual Predictor Variables

\begin{tabular}{|l|l|l|l|l|l|l|l|}
\hline & $\begin{array}{l}\text { Board } \\
\text { Independence }\end{array}$ & $\begin{array}{l}\text { Board } \\
\text { Size }\end{array}$ & $\begin{array}{l}\text { Board } \\
\text { Composition }\end{array}$ & $\begin{array}{l}\text { Board } \\
\text { Gender } \\
\text { Diversity }\end{array}$ & $\begin{array}{l}\text { Corporate } \\
\text { Governance }\end{array}$ & $\begin{array}{l}\text { Capital } \\
\text { Structure }\end{array}$ & $\begin{array}{l}\text { Corporate } \\
\text { Value }\end{array}$ \\
\hline $\begin{array}{l}\text { Board } \\
\text { Independence }\end{array}$ & 1.00 & -0.07 & $-0.38^{* *}$ & 0.08 & $0.47^{* *}$ & -0.01 & $0.15^{*}$ \\
\hline Board Size & -0.07 & 1.00 & $0.17^{* *}$ & -0.10 & $0.74^{* *}$ & 0.05 & -0.06 \\
\hline $\begin{array}{l}\text { Board } \\
\text { Composition }\end{array}$ & $-0.38^{* *}$ & $0.17^{* *}$ & 1.00 & $-0.21^{* *}$ & $0.14^{*}$ & 0.01 & $-0.32^{* *}$ \\
\hline Board Gender & 0.08 & -0.10 & $-0.21^{* *}$ & 1.00 & $0.29^{* *}$ & 0.09 & -0.06 \\
\hline
\end{tabular}




\begin{tabular}{|l|l|l|l|l|l|l|l|}
\hline Diversity & & & & & & & \\
\hline $\begin{array}{l}\text { Corporate } \\
\text { Governance }\end{array}$ & $0.47^{* *}$ & $0.74^{* *}$ & $0.14^{*}$ & $0.29 * *$ & 1.00 & 0.07 & -0.08 \\
\hline $\begin{array}{l}\text { Capital } \\
\text { Structure }\end{array}$ & -0.01 & 0.05 & 0.01 & 0.09 & 0.07 & 1.00 & $-0.20^{* *}$ \\
\hline $\begin{array}{l}\text { Corporate } \\
\text { Value }\end{array}$ & $0.15^{*}$ & -0.06 & $-0.32^{*}$ & -0.06 & -0.08 & $-0.20^{* *}$ & 1.00 \\
\hline
\end{tabular}

** Correlation is significant at the 0.01 level and * at the 0.05 level.

Source: Research Data

As shown in table 4 above, positive statistical relationship was noted between Board Independence and Corporate Governance, and Corporate Value $(\mathrm{r}=.47, \mathrm{p}<0.01(\mathrm{r}=.15, \mathrm{p}<0.05)$ respectively. While a negative statistical relationship existed between Board Independence and Board Composition $(\mathrm{r}=-.38, \mathrm{p}<0.01)$. This means that as board independence increases, Composite Corporate Governance, and Corporate Value also increases. However, an increase in Board Independence results in a decrease in board composition as the number of executive directors is expected to decrease as non - executive increases.

\subsection{Intervening Effect of Capital Structure on the Relationship between Corporate Governance and Corporate Value}

The objective was to assess the intervening effect of Capital Structure on the Relationship between Corporate Governance and Corporate Value of companies listed at the NSE. According to Baron and Kenny's (1986) approach, four steps were followed to test effect of the intervening variable on the relationship between the independent and dependent variables. These steps were adopted in the study. In step one of the interventions, regression analysis was performed to assess the relationship between Corporate Value (dependent variable) and Corporate Governance (independent variable) while ignoring the intervening variable (Capital Structure).

The second step of the intervening model involved performing a regression analysis to assess the relationship between Capital Structure (intervening variable) and Corporate Governance (independent variable) ignoring the Corporate Value (dependent variable). The third step of the intervention involves performing regression analysis to assess the relationship between Capital Structure (intervening variable) and Corporate Value (dependent variable) ignoring the independent variable (Corporate Governance). The fourth step of the intervention analysis was performed to assess the relationship between Corporate Value (dependent variable), Capital Structure (intervening variable), and Corporate Governance (independent variable).

According to Baron and Kenny (1986) approach, for intervention effect to be considered positive, the analysis must fulfill four conditions namely: there must be a significant relationship between the independent variable and dependent variable in the absence of an intervening variable; there must be a significant relationship between the independent variable and the intervening variable; there must be a significant relationship between an intervening variable and the dependent and finally when controlling for the effects of the intervening variable on the dependent variable, the effect of the independent variable on the dependant variable is significant in the presence of the intervening variable.

The composite measure of Corporate Governance was used while Capital Structured as measured by liquidity and Corporate value as measured by Tobin Q were used. A hypothesis was developed and tested for the intervening effect of Capital Structure on the Relationship between Corporate Governance and Corporate Value. The following null hypothesis was tested.

H1: No significant intervening effect of capital structure on the relationship between corporate governance and corporate value.

The results are shown in Table 5.2 below.

Table 5 Regression Results of Corporate Governance (CG), Capital Structure (CS) and Corporate Value (CV) 


\begin{tabular}{|c|c|c|c|c|c|c|c|c|}
\hline Variables & $\beta$ & SE & Std. $\beta$ & $t$ & $\mathbf{R}$ & $\mathbf{R}^{2}$ & $\Delta R^{2}$ & $F$ \\
\hline Model $1^{a}$ & & & & & 0.76 & 0.036 & 0.031 & $1.66^{* *}$ \\
\hline Constant & 1.234 & 0.178 & & $6.919^{* *}$ & & & & \\
\hline CG & -0.513 & 0.398 & -0.076 & $-1.288^{\star *}$ & & & & \\
\hline Model $2^{b}$ & & & & & 0.07 & 0.005 & 0.004 & 1.436 \\
\hline Constant & 0.302 & 0.085 & & $3.538^{* *}$ & & & & \\
\hline CG & 0.228 & 0.191 & 0.07 & 1.199 & & & & \\
\hline Model $3^{c}$ & & & & & 0.199 & 0.04 & 0.02 & $11.883^{* *}$ \\
\hline Constant & 1.174 & 0.054 & & $21.901^{* *}$ & & & & \\
\hline $\mathrm{CS}$ & -0.416 & 0.121 & -0.199 & $-3.447^{* *}$ & & & & \\
\hline Model $4^{d}$ & & & & & 0.208 & 0.043 & 0.033 & $6.518^{* *}$ \\
\hline Constant & 1.357 & 0.179 & & $7.581^{* *}$ & & & & \\
\hline CG & -0.42 & 0.392 & -0.062 & -1.071 & & & & \\
\hline $\mathrm{CS}$ & -0.407 & 0.121 & -0.195 & $-3.364^{* *}$ & & & & \\
\hline
\end{tabular}

a. Dependent variable: Corporate Value

b. Dependent Variable: Capital Structure

c. Dependent Variable: Corporate Value

d. Dependent Variable: Corporate Value

\section{Source: Research Findings}

Multiple linear regression was computed to assess the relationship Between Corporate Governance, Capital Structure, and Corporate Value for firms listed at the NSE. As shown in Table 5 above, in step one of the analysis (the main effect), there was a significant relationship between Corporate Governance and Corporate Value $\left(\mathrm{F}=1.66, \mathrm{p}<.01, \mathrm{R}^{2}=.036, \Delta \mathrm{R}^{2}=.031\right)$. The test of slope shows that the regression coefficient $(\beta)$ value of Corporate Governance was -.513 with a significant t-value. This indicates that Corporate Governance is a significant predictor variable $(\mathrm{p}<.01)$ and therefore significant relationship exists between Corporate Governance and Corporate Value.

In step two there was no significant relationship between Corporate Governance and Capital Structure $\left(\mathrm{F}=1.436, \mathrm{p}>0.05, \mathrm{R}^{2}=.005, \Delta \mathrm{R}^{2}=.004\right)$. The test of the slope shows that the regression coefficient $(\beta)$ value of Corporate Governance 0.228 with an insignificant t-value of 1.199 . This indicates that Corporate Governance is not a significant predictor of Capital Structure $(\mathrm{p}>.05)$ and therefore, there is no significant relationship between Corporate Governance and Capital Structure.

In step three there was a significant relationship between Capital Structure and Corporate Value $(\mathrm{F}=11.883$, $\mathrm{p}<0.01, \mathrm{R}^{2}=.04, \Delta \mathrm{R}^{2}=.02$ ). The test of the slope shows the regression Coefficient $(\beta)$ value of Capital Structure .416 with a significant t-value of -3.447 . This indicates that Capital Structure is a significant predictor of Corporate Value $(\mathrm{p}<0.01)$ and therefore a significant relationship exists between Capital Structure and Corporate Value.

In the fourth step, there was a significant relationship between Corporate Governance, Capital Structure, and Corporate Value $\left(\mathrm{F}=6.518, \mathrm{p}<.01, \mathrm{R}^{2}=.043, \Delta \mathrm{R}^{2}=.33\right)$. The test of the slope shows that the regression coefficient ( $\beta$ ) value of Corporate Governance was -.42 with a non-significant $t$-value of $-1.071 \quad(\mathrm{p}<.05)$. The regression coefficient $(\beta)$ value of Capital Structure was -.407 with a significant $t$-value of $-3.364(p<.01)$. This indicates that Corporate Governance and Capital Structure significantly predict Corporate Value. Although Capital Structure still predicts Corporate Value even when Corporate Governance controlled, Corporate Governance did not predict Capital Structure in step two above. If the mediator is not relating to the causation variable, then it cannot mediate the relationship. $\beta_{2}(0.228, p>0.05)$ should have been significant for a relationship to exist. In this case, therefore, CS has no significant intervening effect on the relationship between CC and CV. The Baron and Kenny's (1986) rule requires that all the four steps predict positive relationships between the variables, therefore Capital Structure has not intervened in the Relationship between Corporate Governance and Corporate Value. We fail to reject the null hypothesis $\mathrm{H}_{1}$.

\subsection{Findings and Conclusion}

The study was guided by the Agency Theory. The theory proposes that the separation of ownership from control leads to agency problems whereby management operates the firm aligning with their own interests, and not of shareholder's. Agency relationship in listed firms create opportunities for managers to spend firm resources maximizing their utilities rather than maximizing the shareholders wealth. The study was based on positivism research philosophy since there was evidence of formal propositions, quantifiable measures of variables, 
hypothesis testing, and drawing of inferences about the relationships among the study variables. The study adopted a penal data longitudinal descriptive design as there were clearly stated hypothesis and specified secondary data. The population of the study consisted of all the sixty-four firms listed at the NSE as of 31st December 2017.

Secondary data was collected from the annual reports and accounts of firms listed at the NSE as well as web sites of these companies and where necessary, information was obtained directly from the company. Descriptive measures of the data involved mean, maximum, minimum, standard error of estimate, skewness, and kurtosis. The diagnostic tests done on the data included linearity, multivariate normality, multicollinearity, independence, and homoscedasticity. The correlation analysis, multiple (hierarchical) regression analysis, and the Baron and Kenny (1986) approach for testing intervention and moderation were used in hypothesis testing.

The objective was to assess the intervening effect of Capital Structure on the Relationship between Corporate Governance and Corporate Value of NSE listed firms. The hypothesis $\left(\mathrm{H}_{1}\right)$ investigated the intervening effect of Capital Structure on the relationship between Corporate Governance and Corporate Value of firms listed at the NSE. The finding was that there is no intervening effect of Capital Structure on the relationship $(p<.01)$ between Corporate Governance and Corporate Value. The finding fails to reject the null hypothesis. The study concludes that Capital Structure does not intervene in the relationship between Corporate Governance and Corporate value. Whereas Corporate Governance in isolation, significantly affects Corporate Value, when intervened by Capital Structure, there is no insignificant relationship. The implication of this conclusion is that the Capital Structure may not be effective in influencing the Corporate Governance practices adopted by corporations listed at the Nairobi Security Exchange. However, the overall board of directors appears to be effective in ensuring that listed companies at NSE maximize shareholders' wealth.

\subsection{Contribution of the study}

The findings of this study make several contributions to knowledge on Corporate Governance, Capital Structure, and Corporate Value. Further, it has several implications for the board of directors, corporate management, regulatory authorities, and investors. It makes a significant contribution to the agency theory by showing interaction mechanisms among variables. Another contribution of this study was to evaluate the intervening effect of Capital Structure on the Relationship between Corporate Governance and Corporate Value. The direct effect of Capital Structure and Corporate Value has been evaluated by several past studies (Adera et al., 2015; Bokhari \& Khan, 2013, and Dumont \& Svensson, 2014). Other studies have assessed the direct effect of Corporate Governance on Corporate Value (Padmanabha \& Rathish, 2017 and Vincent et al., 2015). The findings of these past studies have not only been contradictory but also inconclusive. This study sheds light on evaluating the intervening effect of Capital Structure on the Relationship between Corporate Governance and Corporate Value. Given that Baron and Kenney (1986) approach was used in the analysis, both the direct intervening effects were evaluated.

\subsection{Limitation of the Study}

The study adopted a descriptive research design since it had clearly stated hypotheses or investigative questions. The design however has the disadvantage that it cannot establish causality among variables. Thus, while the study could establish the direction and nature of relationships among variables, it could not establish the causality effects among the variables. The five-year data, (2013-2017) may not be long enough because the market and government issues keep changing from time to time. The period of data can be longer to make the results more conclusive to justify the dynamic nature of the market and governing laws and regulations. The above limitations do not dilute the quality of the study.

\subsection{Recommendation and Policy Implication}

The findings also seem to extend the scope of corporate governance beyond the usual corporate governance scope by roping in capital structure as part and parcel of corporate governance. Shareholders, board, and management should ensure that capital structure is a key element of corporate governance like being employed to reduce agency costs through influencing optimal management decision making among others. Another recommendation for practice is that financial market analysts and investors can apply the study to bring sound regulation in financial markets where the analysts promote firms that have adopted optimally corporate codes of good practice, highlighting their performance and availing information to regulatory bodies and potential investors. The investors would also prefer to invest mostly in well-governed firms. Regulators based in information provided by the analysts and firms' own reports should then ensure compliance adherence. Management should be interested in implementing regulations and controls to achieve high profits and maximum shareholders' capital.

\subsection{Suggestion for Future Research}

Further research could be conducted to introduce more or different variables for testing both moderation and intervening effect mediating the effect of Corporate Governance on Corporate Value. Secondly, the current study 
used quantitative measures of Corporate Value. A similar study could be conducted based on qualitative and quantitative measures of Corporate Value. This would further widen the scope of the current study. Future researchers need to incorporate other performance measures, both financial and non-financial other than just Tobin Q considered above. A similar study could be replicated in other countries regionally and internationally. This would further validate the findings of the current and future studies. This should involve expanding the study to look at regional markets like COMESA or even do more detailed studies focusing on individual segments of each market understudy to asses' variations if any in result obtained. Additional or different variables other than corporate governance, capital structure, and ownership structure can also be considered in the future to enrich corporate governance studies generally and deepen understanding even further.

\section{References}

Adera, W. O., Anyango, W., \& Rotich, G. (2015). Capital structure and corporate performance of manufacturing companies listed in Nairobi Securities Exchange. International Academic Journal of Economics and Finance, $1(5), 1-9$.

Ali, M. (2018). Impact of Corporate Governance On Firm's Financial Performance: A Comparative Study Of Developed And Non Developed Markets. Journal of Business Management and Economic Research 2(1), $15-30$

Alqisie, A. (2014). Do corporate governance indicators lead the firm to adopt high/low level of financial leverage? Case of Jordan. Journal of Management Research, 6, 99-113.

Anderson. E. A, Becker. O.P \& Campbell.H. O (2014). Insight of corporate governance Theories. Journal of Business and Management, 1(1), 52-63.

Bader, Y., (2016). The Effect of Strategic Orientation on Organizational Performance: the Mediating role of innovation. International. Journal of Communications, Network and System Sciences, 9, 478-505

Baron, R. M., \& Kenny, D. A. (1986). The moderator-mediator variable distinction in social psychological research, conceptual, strategic, and statistical considerations. Journal Personality and Social Psychology, 5 (6), 1173-1182.

Beck, J. B., \& Wiersema, M. F. (2013). Executive decision-making: Managerial capabilities to the resource portfolio and strategic outcomes. Journal of Leadership \& Organizational Studies, 20, 408- 419.

Bhaskar, R. (2014). The possibility of naturalism: A philosophical critique of the contemporary human sciences. Routledge.

Bokhari, H. W., \& Khan, M. A. (2013). The Impact of Capital Structure on Firm's Performance (A Case of NonFinancial Sector of Pakistan). European Journal of Business and Management 5(31), 111-137.

Calomiris, C. W., \& Carlson, M., (2016). Corporate Governance and Risk Management at Unprotected Banks: National Banks in the 1890s. Journal of Financial Economics, 119(3), 512-532.

Capital Market Authority, (2019), the Kenya financial sector performance analysis report 2018.Financial Sector Regulators Forum, June 2019, Issue No. 5.

Carter, S. M., \& Greer, C. R. (2013). Strategic leadership: Values, styles, and Organizational performance. Journal of Leadership \& Organizational Studies, 20, 379-393.

Carty, R., \& Weiss, G. (2012). Does CEO duality affect corporate performance? Evidence from the US Banking crisis. Journal of financial regulation and compliance, 20 (1) 26-40.

Central Bank of Kenya, (2019), the Kenya financial sector stability report 2017.Financial Sector Regulators Forum, September 2019, Issue No. 9.

Chen, L. (2012). The effects of ownership structure on firm performance: Evidence from Scandinavian Countries. Journal of Finance \& International business, 3(8), 18 - 39.

Cooper, C. R. \& Schindler, P.S. (2008). Business Research Methods 10th edition. Boston: McGraw-Hill.

Creswell, J. W. (2013). Research design: Qualitative, quantitative, and mixed methods approaches. Sage publications.

Dominic, O. O., \& Memba, F. (2015). Effect of corporate governance practices on financial performance of public limited companies in Kenya. International Journal of Management and Commerce Innovations, 1(3), 122132.

Donaldson, L., \& Davis, J. H. (1994). Boards and company performance - Research challenge the conventional wisdom, corporate governance. An International Review, 2 (3), 65-91.

Driffield, N., Mahambare, V. \& Pal, S. B. (2005). How Ownership Structure Affects Capital Structure and Firm Performance? Recent Evidence from East Asia. Department of Economics and Finance, Brunel University, UK

Durbin. J and G. S. Watson (1951). Testing for serial correlation in least squares regression. II. Biometrika, 38, $159-178$.

Dumont \& Svensson. (2014). Capital Structure and firm performance - A Swedish Public Company. Bachelor Thesis Business Administration, Handelshogskolan Goteborgs University. 
Githira, W. C. \& Nasieku, T. (2015). Capital structure determinants among companies quoted in Securities Exchange in East Africa. International Journal of Education and Research, 3 (5), 483 - 496.

Gujarati, D. (2003). Basic Econometrics. 4th ed. New York: McGraw Hill, 638-640.

Hasan, A., \& Butt, S.A. (2009). Impact of Ownership Structure and Corporate Governance on Capital Structure of Pakistani Listed Companies. International Journal of Business and Management, 4(2), 50-57

Haque, F. \& G. Arun, T. G. (2016). Corporate governance and financial performance: an emerging economy perspective. Investment Management and Financial Innovations, 13(3-1).

Jensen, M., \& Meckling, W. (1976). Managerial behavior, agency costs and ownership structure. Journal of Financial Economics, 3, 305-360.

Kothari, (2004). Research Methods: Methods and Techniques. New Delhi: AGE International.

Lishenga, J. (2012). Corporate governance reaction to declining firm performance: Evidence from NSE, African Journal of Business Management. (1), $24-42$.

Lumumba, P. (2015). A value proposition for corporate Governance. Governance. Journal of the Institute of Certified Public Secretaries of Kenya, 1, 24-28.

Mang'unyi, E. E. (2011). Ownership Structure and Corporate Governance and Its Effects on Performance: A Case of Selected Banks in Kenya. International Journal of Business Administration, 2(3), 2-18.

Modigliani, F., \& Miller, M. (1958). The cost of capital, corporation finance and the theory of investment, American Economic Review 48, 261-297.

Morrison, J. R \& Jenson, N. J., (2013). The strategic use of corporate board committees, California Management Review, 30 (1), 109-125.

Okiro, K. O. (2014). Corporate governance, capital structure, regulatory compliance and performance of firms listed at the East African community securities exchange (Doctoral dissertation, University of Nairobi).

Okiro, K., Aduda, J., Omoro, N. (2015). Effect of corporate governance and capital structure of performance of firms listed at the East African community securities exchange. European Scientific Journal, 11(7), 504-533.

Opiyo.E. (2013). Effects of corporate governance on insider trading A case of listed companies on Nairobi securities exchange. Prime Journal of business administration and Management 9(5), 49 - 61.

Padmanabha, R.B. \& R. Rathish, (2017). Corporate governance and firm performance in Malaysia. Corporate Governance: The International Journal of Business in Society, 17(5): 896-912.

Peters, G. T., \& Bagshaw, K. B. (2014). Corporate governance mechanisms and financial performance of listed firms in Nigeria: a content analysis. Global Journal of Contemporary Research in Accounting, Auditing and Business Ethics, 1(2),103-128.

Proudfoot, D., (2016). Board Member. Res. Organ. Behav., 34 (1), 683-695.

Robbins, H., \& Judge, G., (2017). Impact of corporate governance on the performance of commercial banks in Zimbabwe. Mediterranean Journal of Social Sciences, 5(15), 203-221.

Rose, C. (2017). The relationship between corporate governance characteristics and credit risk exposure in banks: Implications for financial regulation. European Journal of Law and Economics, 43(1), 167-194.

Sekaran, U., \& Bougie, R. (2009). Research Methods for Business: A Skill Building Approach, (5 th edition). London: John Wiley \& Sons Ltd.

Sen, P. K., Das, D., \& Sharma, P. (2014). Relevance of Financial Literacy for the Growth of National Economy and Elimination of Frauds. The MA Journal, 49(6), 41-44.

Shapiro, S. S., and Wilk, M. B., (1965). An Analysis of Variance Test for Normality (Complete Samples). Biometrika, 52, (3 - 4), 591-611.

Solomon, M. C., Gerald, M. M., Alala, O.B., Douglass, M. \& Maokomba, O. C. (2013). Capital Structure and Corporate Governance Practices. Evidence from listed non-Financial Firms on Nairobi security exchange. Journal of Business Management. 10(2), 8-16.

Stiglbauer, M., (2011). Impact of Capital and Ownership Structure on Corporate Governance and Performance: evidence from an insider system. Journal of Problems and Perspective in Management, 9(1), 16-23.

Velte, P., (2017). Do women on board of directors have an impact on corporate governance quality and firm performance? A literature reviews. International Journal of Sustainable Strategic Management, 5(4), 302346.

Vincent O. O., K’Obonyo, P. O., Ogutu, M., \& Bosire, E. M. (2015). Board composition and financial performance: Empirical analysis of companies listed at the Nairobi securities exchange. International Journal of Economics and Financial Issues, 5(1), 23-43.

Wagana, D. \& Karanja, K., (2015). The influence of corporate governance on corporate performance among manufacturing firms in Kenya: a theoretical model, International Journal of Academic Research in Business and Social Sciences, 5, (4), 258-272.

Wanyoike \& Nasieku, (2015). Capital structure determinants among companies quoted in Securities Exchange in East Africa. International Journal of Education and Research, 3(5), 23-58.

Warokka, A., Herrera, J.J.D., \& Abdullah, H.H., (2011). East Asia Corporate Governance: A test of the relation 
between capital structure and firm performance, International Journal of Economics and Finance studies, $3(2), 1-10$

Zabri, S. M., Ahmad, K., \& Wah, K. K., (2016). Corporate governance practices and firm performance: Evidence from top 100 public listed companies in Malaysia. Procedia Economics and Finance, 35, 287-296. 